\title{
Editorial
}

\section{Progressing Climate Changes and Deteriorating Air Quality as One of the Biggest Challenges of Sustainable Development of the Present Decade in Poland}

\author{
Kazimierz Gaj ${ }^{\circledR}$, Urszula Miller ${ }^{(}$and Izabela Sówka *(D) \\ Department of Environment Protection Engineering, Faculty of Environmental Engineering, Wroclaw University \\ of Science and Technology, Wyb. Wyspianskiego 27, 50-370 Wroclaw, Poland; kazimierz.gaj@pwr.edu.pl (K.G.); \\ urszula.miller@pwr.edu.pl (U.M.) \\ * Correspondence: izabela.sowka@pwr.edu.pl; Tel.: +48-71-320-25-60
}

Received: 4 August 2020; Accepted: 6 August 2020; Published: 7 August 2020

check for updates

\begin{abstract}
Among the biggest challenges facing our civilization is slowing down the rate of climate change and improving air quality in cities. This cannot be achieved in isolation from the sustainability and intensification of relevant research. The aim of this Special Issue: Current Trends in Emission Control and Forecasting of Air Quality and Climate Changes is to publish selected high-quality papers from the 15th Scientific Conference POL-EMIS 2020: Current Trends in Air and Climate Protection-Control Monitoring, Forecasting, and Reduction of Emissions (19-21 October 2020, Wroclaw) and other papers related to the development of: low-emission fuels, industrial technologies, and energy generation, including renewable energy sources (RES); technology for reducing/eliminating emissions from low municipal sources and transport; innovative methods of waste gas purification; emission and immission control methods (including odors); prospective ways of counteracting climate change; indoor air protecting methods; development of mathematical modeling of air quality; new directions in forecasting the effects of air pollution and climate change and air quality management.
\end{abstract}

Keywords: air quality; climate protection; greenhouse gases; renewable energy; air pollution control

The problem of climate change is global, so only global system changes can respond to it. They should apply to both producers and consumers. In addition to the obvious changes in energy acquisition methods and industrial technologies towards a low-carbon and resource-efficient economy, it will also be necessary to re-evaluate our daily behaviors and habits. Focusing on fossil coal as one of the main energy fuels of some economies (i.e., China, USA, India, Australia, Poland), in addition to contributing to global warming, leads to health-threatening local air pollution. Emissions from the use of fossil fuels in domestic heating systems and transport are particularly dangerous, especially in Poland, where $84 \%$ of all household coal consumption in the EU-28 takes place [1], and solid fuel consumption in this sector reaches $45 \%$ (while in the entire EU-28-according to Eurostat data [2]—it is below $5 \%$ ). WHO estimates that 2 million people die annually due to air pollution. In Poland, air pollution is suspected to cause more than 40,000 deaths a year. Although this number is much higher than the number of deaths caused by the current SARS-CoV-2 virus epidemic, it does not cause adequate reactions of decision-makers. Fossil fuels still account for around $80 \%$ of the total global primary energy consumption, with coal at $26 \%$ (a decrease of only $2 \%$ in $2010-2019$ ) [3] Poland is among the countries with the most unfavorable structure of energy carriers from the point of view of climate change and air pollution. According to the official Polish statistical data [4], the share of fossil fuels in primary energy consumption exceeds $83 \%$, and the share of coal is $76 \%$. The global mix of 
energy carriers in electricity production seems more optimistic-the share of fossil fuels is $62 \%$, while the share of coal is 36\% [3]. In the case of Poland, these data, as of 3 March 2020, are $90.0 \%$ and $82.1 \%$, respectively [5].

Reducing the pace of climate change and improving air quality cannot be achieved without switching economies to renewable energy sources. So far, however, this process is very slow. The share of renewable energy sources (RES) in the global structure of primary energy demand increased in $2000-2019$ by only $1 \%$-from $13 \%$ to $14 \%$. On the other hand, a faster increase in RES use is observed in electricity production-from $18 \%$ in 2000 (17\%-hydropower and $1 \%$-biomass and waste) to $28 \%$ in $2019(16 \%$-hydropower, 3\%—-biomass and waste, 5\%-wind, 3\%-solar farm, 1\%-other renewables) [3]. The situation is even more favorable in the $\mathrm{EU}$, where the share of renewable energy in electricity generation exceeded $30 \%$ in 2017 , and the overall structure of obtaining primary energy from renewable sources is as follows: solid biofuels $-42 \%$, wind $-13.8 \%$, water $-11.4 \%$, biogas $-7.4 \%$, liquid biofuels- $6.7 \%$, sun-6.3\%, and others- $12.4 \%$. Against this background-according to official statistic data for 2017 [6] — Poland is distinguished by a higher share of solid biofuels $(67.7 \%)$ and a much lower share of other RES.

Solar energy seems to be the most promising among RES today. This is indicated by rapidly falling prices of solar panels and a systematic increase in their efficiency. In Poland, in 1996-2016, prices of photovoltaic modules dropped by almost 10 times [7] and the installed capacity of photovoltaic plants as of May 2020—according to data from the Energy Market Information Center (CIRE)-amounted to $1950 \mathrm{MW}$, showing an increase of $181 \% \mathrm{y} / \mathrm{y}$. The mentioned installed capacity includes both prosumer micro-installations, small commercial plants, and large solar farms. Nevertheless, onshore wind energy has been developing dynamically in recent years. Today, its share among RES in Poland is dominant (about $60 \%$ ). The planned development of offshore wind energy in the Baltic Sea creates even greater perspectives [8]. The withdrawal of the EU from supporting the ecologically, technically, and economically controversial co-firing of biomass with coal, which a few years ago was a dominant RES in some European countries, is symptomatic. For example, in Poland, the share of solid biofuels in this respect in 2012 exceeded $80 \%$. It was the cheapest and fastest way to achieve the national target of RES share in gross final energy consumption (EU-20\% and Poland-15\%, by 2020) without significant investments. There were then paradoxical and ecologically absurd situations of importing biomass from distant corners of the world, e.g., from Africa (coconut shells).

Thanks to the abandonment of solid fuel combustion in domestic furnaces, the development of low-emission transport and the progress in the field of industrial waste gas treatment, the problem of air pollution in many developed countries, has been largely solved. Technologies for dedusting and cleaning flue gases from acidic pollutants can be considered today as mastered, effective, and generally available. The fastest development in the methods of comprehensive flue gas treatment in recent years concerned numerous waste incineration plants. For other pollutants, e.g., volatile organic compounds (VOCs) including odors, the search for the most efficient and environmentally sustainable technologies is still ongoing. It seems that in this case, particularly large development potential lies in biological methods.

Biological methods allow us to achieve high efficiency of waste gas treatment with lower energy expenditure compared to other methods, and with a limited formation of waste by-products. For this reason, the development of biotechnological methods is the future of the industry in the context of protecting the atmosphere and preventing climate change [9]. The general development of biotechnology allows for an increasing use of biological methods in gas purification, and emerging needs favor innovation. For example, biofiltration is no longer limited to removing hydrophilic contaminants and contaminants with good bioavailability. Industrial gases containing large amounts of hydrophobic volatile organic compounds (VOCs) can be successfully removed by biological methods. Research in this field is aimed at increasing the solubility of pollutants, increasing their bioavailability, optimizing the process conditions, and selecting the appropriate consortia of microorganisms and their adaptation. The latest research indicates the possibility of using in vitro adapted microorganisms and 
microscopic fungi [10], the addition of surfactants [11], and biofiltration with pretreatment (ultraviolet and photocatalytic oxidation and innovative bioreactors (i.e., RDB — the rotating drum biofilter)) [12]. A comparison of the basic biological methods (conventional biofilter, biotrickling filter, and bioscrubber) is presented in the article by Gospodarek et al. [13].

Adsorption methods are also being developed, e.g., using new zeolites and polymer resins [14]. Numerous studies are also conducted on the use of membrane techniques-not only for enriching gaseous fuels (e.g., $[15,16])$ or $\mathrm{CO}_{2}$ sequestration from flue gases (e.g., $\left.[17,18]\right)$ but also for the selective removal of $\mathrm{H}_{2} \mathrm{~S}$ [19]. This is a relatively new method in gas purification, but it is rapidly gaining importance, due to the increasing availability of selective and cheap polymeric materials.

In order for air quality management to be effective, it is necessary to further develop methods of mathematical modeling of pollutant dispersion, especially for a larger spatio-temporal scale. More accurate models are needed, creating the possibility to take into account the time changes in emission and conditions of transport of pollutants in the air, as well as their physicochemical changes. The next generation of Gaussian models should be developed using the continuous dependence of the parameters of the emitted plume on meteorological parameters, as well as more complex numerical diffusion models. Progress in this area may be evidenced by the increasing use in domestic decision-making practices of the "puff" or "segment" type of developed Gaussian models (e.g., in air protection programs in Poland).

Due to the above-mentioned problems, there is an urgent need for new, low-emission industrial technologies, effective emission control methods, as well as new air quality and climate change forecasting tools. Supporting development in these fields was precisely the main goal of the originators of this Special Issue.

Author Contributions: Conceptualization, K.G.; methodology, G.K., U.M. and I.S.; writing-original draft preparation, K.G., U.M. and I.S.; writing-review and editing, K.G., U.M. and I.S.; supervision, I.S. All authors have read and agreed to the published version of the manuscript.

Funding: This work was co-financed within the "Excellent Science" program of the Polish Ministry of Science and Higher Education.

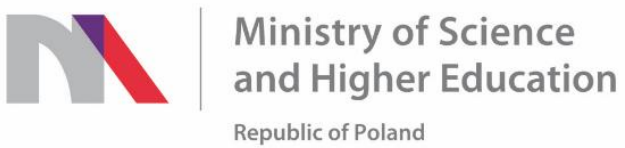

Conflicts of Interest: The authors declare no conflicts of interest.

\section{References}

1. Energy Consumption in Households in 2018; Statistics Poland (GUS): Warsaw, Poland, 2019.

2. EUROSTAT. European Commission 2020. Available online: https://ec.europa.eu/eurostat/statistics-explained/ index.php?title=File:Share_of_fuels_in_the_final_energy_consumption_in_the_residential_sector_for_ space_heating,_2018_(\%25).png\&oldid=487954 (accessed on 29 June 2020).

3. IEA (International Energy Agency). Global Energy Review 2019. The Latest Trends in Energy and Emissions in 2019. Available online: https://www.iea.org/data-and-statistics (accessed on 22 June 2020).

4. Energy Statistics in 2017 and 2018; Statistics Poland (GUS): Warsaw, Poland, 2019.

5. Energy Market Information Center (CIRE). Available online: https://rynek-energii-elektrycznej.cire.pl (accessed on 24 June 2020).

6. Energy 2019; Statistics Poland (GUS): Warsaw, Poland, 2019.

7. Niechaj, M. Effective use of photovoltaic systems in polish conditions. J. Ecol. Eng. 2016, 17, 147-154. [CrossRef]

8. Polish Energy Policy until 2040 (Project); Polish Ministry of Energy: Warsaw, Poland, 2019.

9. Gabaldon, C.; San-Valero, P.; Quijano, G. Current challenges and perspectives in gas fluxes biotreatment. In From Biofiltration to Promising Options in Gaseous Fluxes Biotreatment; Elsevier Inc.: Amsterdam, The Netherlands, 2020. [CrossRef] 
10. Vergara-Fernández, A.; Revah, S.; Moreno-Casas, P.; Scott, F. Biofiltration of volatile organic compounds using fungi and its conceptual and mathematical modeling. Biotechnology 2018, 36, 1079-1093. [CrossRef] [PubMed]

11. Miller, U.; Sówka, I.; Adamiak, W. The use of surfactant from the Tween group in toluene biofiltration. Arch. Environ. Prot. 2020, 46, 53-57. [CrossRef]

12. Cheng, Y.; He, H.; Yang, C.; Zeng, G.; Li, X.; Chen, H.; Yu, G. Challenges and solutions for biofiltration of hydrophobic volatile organic compounds. Biotechnol. Adv. 2016, 34, 1091-1102. [CrossRef] [PubMed]

13. Gospodarek, M.; Rybarczyk, P.; Szulczyński, B.; Gębicki, J. Comparative Evaluation of Selected Biological Methods for the Removal of Hydrophilic and Hydrophobic Odorous VOCs from Air. Processes 2019, 7, 187. [CrossRef]

14. Gaj, K. Adsorptive Biogas Purification from Siloxanes-A Critical Review. Energies 2020, 13, 2605. [CrossRef]

15. Chen, X.; Vinh-Thang, H.; Ramirez, A.A.; Rodrigue, D.; Kaliaguine, S. Membrane gas separation technologies for biogas upgrading. RSC Adv. 2015, 5, 24399-24448. [CrossRef]

16. Poudel, J.; Choi, J.H.; Oh, S.C. Process Design Characteristics of Syngas $\left(\mathrm{CO} / \mathrm{H}_{2}\right)$ Separation Using Composite Membrane. Sustainability 2019, 11, 703. [CrossRef]

17. Klingberg, P.; Wilkner, K.; Schlüter, M.; Grünauer, J.; Shishatskiy, S. Separation of Carbon Dioxide from Real Power Plant Flue Gases by Gas Permeation Using a Supported Ionic Liquid Membrane: An Investigation of Membrane Stability. Membranes 2019, 9, 35. [CrossRef] [PubMed]

18. Sarfraz, M.; Ba-Shammakh, M. Water-stable ZIF-300/Ultrason ${ }^{\circledR}$ mixed-matrix membranes for selective $\mathrm{CO}_{2}$ capture from humid post combustion flue gas. Chin. J. Chem. Eng. 2018, 26, 1012. [CrossRef]

19. Akhmetshina, A.I.; Yanbikov, N.R.; Atlaskin, A.A.; Trubyanov, M.M.; Mechergui, A.; Otvagina, K.V.; Razov, E.N.; Mochalova, A.E.; Vorotyntsev, I.V. Acidic Gases Separation from Gas Mixtures on the Supported Ionic Liquid Membranes Providing the Facilitated and Solution-Diffusion Transport Mechanisms. Membranes 2019, 9, 9. [CrossRef] [PubMed]

(C) 2020 by the authors. Licensee MDPI, Basel, Switzerland. This article is an open access article distributed under the terms and conditions of the Creative Commons Attribution (CC BY) license (http://creativecommons.org/licenses/by/4.0/). 